\title{
Identification of an immunogenic 18-kDa protein of Helicobacter pylori by alkaline phosphatase gene fusions
}

\author{
JANE OLIARO, RICHARD D. JOHNSON, WANGXUE CHEN*, VINTON S. CHADWICK* and ALAN \\ MURRAY
}

Institute of Veterinary, Animal and Biomedical Sciences, Massey University, Palmerston North and *Wakefield Gastroenterology Research Centre, Wakefield Hospital, Wellington, New Zealand

\begin{abstract}
The use of alkaline phosphatase fusion methodology to identify Helicobacter pylori exported proteins enabled the identification of an open reading frame (ORF) encoding a highly immunogenic, previously uncharacterised exported protein. The predicted aminoacid sequence displays a typical $\mathrm{N}$-terminal signal peptide and contains regions of $\mathrm{C}$ terminal hydrophobicity consistent with a membrane-associated protein. Southern blot analysis revealed that the gene encoding the protein was absent in several Helicobacter spp. and a combination of PCR and sequence analysis of the amplified gene showed that it is highly conserved amongst isolates of $\mathrm{H}$. pylori. To obtain pure recombinant protein, the gene encoding the protein was cloned and expressed as a $\beta$-galactosidase $(\beta$-gal) fusion in Escherichia coli and the protein was purified by affinity chromatography and proteolytic cleavage of the $\beta$-gal portion. The purified protein, which has an apparent mol. wt of $18 \mathrm{kDa}$, was recognised by antibody present in $71 \%$ of sera from patients infected with $H$. pylori, but in only $16 \%$ of sera from patients with unrelated or no gastrointestinal disease, by Western blot assays. These results indicate that the 18-kDa protein from $H$. pylori is immunogenic and is expressed in vivo.
\end{abstract}

\section{Introduction}

Helicobacter pylori is a gram-negative, spiral bacterium whose discovery and subsequent characterisation has revolutionised understanding of gastrointestinal diseases. It is now accepted as the primary aetiological agent in chronic gastritis, and is strongly associated with both peptic and duodenal ulceration [1]. Evidence supporting the role of $H$. pylori infection as a precursor of gastric carcinoma and mucosa-associated lymph tissue (MALT) lymphoma continues to accumulate [2], making $H$. pylori a significant human pathogen.

The recent release of two $H$. pylori genome sequences $[3,4]$ has accelerated and simplified research in this field, but there is still a large gap in the understanding of the mechanism of $H$. pylori pathogenesis. Despite a vigorous humoral and cellular immune response, the bacteria continue to evade the host's defence mechanisms and persist in the hostile environment of the stomach. Antibodies against various H. pylori proteins

Received 18 July 1999; revised version received 12 Nov. 1999; accepted 18 Nov. 1999.

Corresponding author: Dr A. Murray. can be detected in sera from patients [5], but the identity of many of these proteins remains to be established. Some immunodominant proteins of $H$. pylori that have been well-characterised include the urease subunits [6], the vacuolating cytotoxin (VacA) and cytotoxin-associated protein (CagA) [7], and proteins involved in flagella structure [8]. The discovery that the H. pylori genome harbours a pathogencity island [9] is a major step toward the identification of virulence factors.

The observation in animal models that immunisation with various cell-derived antigens can confer protection against establishment of $H$. pylori infection [10] has led to the search for protective antigens that could be used in a subunit vaccine. Secreted or membraneassociated proteins often play a major role in the pathogenesis of infection [11] and are potentially useful candidates for vaccine development. The lack of a simple antibiotic treatment regimen for $H$. pylori infection and the emergence of antibiotic-resistant strains make the development of a vaccine a desirable goal. Secreted bacterial proteins are also of therapeutic interest, as their cellular location makes them more accessible to drug therapy than cytosolic proteins. 
Gene fusion methodology based on alkaline phosphatase (PhoA) has been used successfully to identify exported proteins in various bacterial systems [12] and has been used in this laboratory to identify $H$. pylori exported proteins [13]. The pJEM11 plasmid vector was first described by Lim et al. [14] and was designed to allow gene fusions between a truncated phoA gene and heterologous genomic DNA. This enables the identification of open reading frames (ORFs) containing a promoter and signal peptide in frame with phoA, which are detected when enzymically active PhoA is transported across the cytoplasmic membrane and turns the recombinant colonies blue in the presence of a chromogenic substrate. The aim of the present study was to identify, by a genetic approach, surface-located or secreted proteins of $H$. pylori that might be involved in pathogenesis and assess their immunogenicity during infection. This report describes the use of phoA gene fusions to identify $H$. pylori genes encoding exported proteins, immunological screening of these fusion proteins, and the expression, purification and investigation of an 18-kDa protein for its distribution among $H$. pylori clinical isolates and its immunogenicity against a panel of sera from patients with or without $H$. pylori infection.

\section{Materials and methods}

\section{Bacterial strains, plasmids and culture media}

The bacterial strains and plasmids used in this study are listed in Table 1. Escherichia coli was routinely grown on Luria Bertani (LB) medium under aerobic conditions at $37^{\circ} \mathrm{C}$. H. pylori isolates (kindly supplied by P. W. O'Toole, Massey University) were grown on Columbia agar plates (Difco) supplemented with horse blood $10 \%$ in a micro-aerobic atmosphere at $37^{\circ} \mathrm{C}$. Genomic DNA was purified by standard procedures [16] and plasmid DNA was prepared with the Bresatec plasmid isolation kit (Bresatec, Australia). Plasmids were maintained in culture containing ampicillin $100 \mu \mathrm{g}$ or kanamycin $30 \mu \mathrm{g}$. PhoA activity was detected by plating the recombinants on LB media containing 5-bromo-4-chlor-3-indolyl phosphate (BCIP) (Sigma) $40 \mu \mathrm{g} / \mathrm{ml}$.

\section{Construction of a plasmid genomic library}

A library of $H$. pylori genomic DNA was constructed in the plasmid vector pJEM11 (kindly supplied by B. Gicquel, Pasteur Institute, Paris, France) as described previously [13]. Briefly, H. pylori was partially digested with Sau3A and fragments ranging from 200 to $2000 \mathrm{bp}$ were purified and ligated into the Bam HI site of the dephosphorylated pJEM11 vector. The ligation mix was used to transform E. coli DH10B by electroporation and the resulting transformations were plated on LB containing the substrate BCIP and kanamycin. Restriction digest analysis of 20 clones revealed that $19(95 \%)$ contained an insert and c. 2$3 \%$ of transformants were blue on BCIP.

\section{DNA sequencing and analysis}

The DNA inserts from pJEM11 plasmid constructs were partially or completely sequenced by automated sequencing with an ABI Prism 337 DNA Sequencer (Perkin Elmer). Oligonucleotide primers were designed to the non-coding strand of phoA (primer pJEM6) and the coding strand of the terminator sequence (primer pJEM7) on the pJEM11 vector - pJEM6: 5' GCAG TAATATCGCCCTGAGCAGC 3'; pJEM7: 5' TTAA

Table 1. Strains and plasmids used in this study

\begin{tabular}{|c|c|c|}
\hline Strain or plasmid & Genotype/phenotype & Source [Reference] \\
\hline \multicolumn{3}{|l|}{ Strains } \\
\hline E. coli $\mathrm{DH} 10 \mathrm{~B}$ & 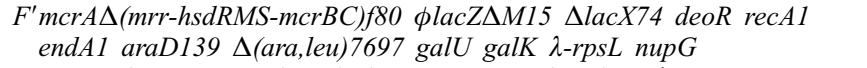 & Life Technologies \\
\hline E. coli XLI-blue & $\begin{array}{l}\text { recAl endA1 gyrA96 thi-1 hsdR17 supE44 relA1 lac }\left[F^{\prime} \text { proAB }\right. \\
\left.\text { lacIqZDM15 Tn10 }\left(\text { tet }^{r}\right)\right]\end{array}$ & {$[16]$} \\
\hline E. coli BL21 (DE3) & hsdS gal ( $\lambda$ cIts857 ind1 Sam7 nin5 lacUV5-T7 gene 1) & {$[16]$} \\
\hline H. pylori 17874 & $\begin{array}{l}\text { H. pylori type strain, } \mathrm{Cag} \mathrm{A}^{+} / \operatorname{Vac} \mathrm{A}^{+} \text {(Type I), identical to } \\
\text { NCTC } 11637\end{array}$ & $\begin{array}{l}\text { Culture collection, University of } \\
\text { Gothenburg, Sweden }\end{array}$ \\
\hline H. pylori MU005 & Clinical isolate, Auckland, $\mathrm{Cag}^{+} / \mathrm{VacA}^{+}$(Type I) & {$[15]$} \\
\hline H. pylori MU007 & Clinical isolate, Auckland, $\mathrm{Cag}^{+} / \mathrm{VacA}^{+}$(Type I) & {$[15]$} \\
\hline H. pylori MU008 & Clinical isolate, Auckland, $\mathrm{CagA}^{-} / \mathrm{VacA}^{-}$(Type II) & {$[15]$} \\
\hline H. pylori MU015 & Clinical isolate, Auckland, $\mathrm{CagA}^{-} / \mathrm{VacA}^{-}$(Type II) & {$[15]$} \\
\hline H. pylori MU016 & Clinical isolate, Auckland, $\mathrm{Cag}^{+} / \mathrm{VacA}^{+}$(Type I) & {$[15]$} \\
\hline H. pylori MU038 & Clinical isolate, Auckland, $\mathrm{CagA}^{-} / \mathrm{VacA}^{-}$(Type II) & {$[15]$} \\
\hline H. pylori MU064 & Clinical isolate, Auckland, $\mathrm{Cag}^{+} / \mathrm{VacA}^{+}$(Type I) & {$[15]$} \\
\hline H. pylori MU091 & Clinical isolate, Auckland, $\mathrm{CagA}^{-} / \mathrm{VacA}^{-}$(Type II) & {$[15]$} \\
\hline H. felis & Cat clinical isolate & P. W. O’Toole \\
\hline H. mustelae 4298 & Laboratory passaged strain & P. W. O’Toole* \\
\hline \multicolumn{3}{|l|}{ Plasmids } \\
\hline pJEM11 & E. coli-mycobacterial shuttle vector carrying a truncated phoA gene & {$[14]$} \\
\hline РJHр20 & PJEM11 carrying part of a $H$. pylori gene encoding an $18-\mathrm{kDa}$ antigen & This study \\
\hline $\mathrm{pXa1}$ & Expression vector $\left(\mathrm{P}_{\text {lac }}: \mathrm{fl}_{\text {ori }}:\right)$ & Boehringer Mannheim \\
\hline pXa-1085 & pXa1 vector containing the $20 / 1-20 / 2$ PCR amplification product & This study \\
\hline
\end{tabular}

* Originally obtained from J. G. Fox, Massachusetts Institute of Technology, MA, USA. 
TTGGGGACCCTAGAGGTCC 3'. Primers were designed and tested for suitability by GeneWorks (Release 2.45, IntelliGenetics, CA, USA). Sequencing contigs were built up with the GeneWorks Sequencing Project document. DNA and protein databases were searched with the BLAST [17] and FASTA servers to identify similarities between the insert DNA and previously identified sequences. The BLAST + BEAUTY algorithm [18] was also used to search databases for sequence similarities and structural motifs. After the release of the entire $H$. pylori genome sequence $[3,4]$ the H. pylori genome databases (HPDB) were searched to identify sequence similarities with the annotated ORFs. The GeneWorks program was used for all other sequence analyses.

\section{Isolation of periplasmic space proteins}

For fractionation of the intracellular, periplasmic and extracellular protein, plasmids were transformed into $E$. coli strain BL21 (DE3). The periplasmic space proteins were isolated by the method of Neu and Heppel [19]. Briefly, the cells were grown in supplemented M63 media to late-log phase (OD 0.7-0.9) and harvested by centrifugation. The supernate was stored as the extracellular fraction. The cells were washed with $10 \mathrm{mM} \mathrm{NaCl}$, then resuspended and agitated gently in sucrose $25 \%$ solution in $1.5 \mathrm{mM}$ EDTA and collected by centrifugation. After adding ice-cold water to shock the cells, the preparation was filtered through a $0.45-$ $\mu \mathrm{m}$ membrane to collect the periplasmic space fraction. The cells were then washed in $10 \mathrm{mM}$ Tris- $\mathrm{HCl}, 1 \mathrm{mM}$ EDTA and sonicated three times for $1 \mathrm{~min}$ with $30-\mathrm{s}$ intervals to release the intracellular protein.

\section{Detection of alkaline phosphatase and $\beta$ - galactosidase activity}

The alkaline phosphatase assays on protein extracts were based on a method originally described by Brickman and Beckwith [20]. Briefly, each protein sample was assayed in duplicate in $1 \mathrm{M}$ Tris, $\mathrm{pH}$ 8. As a control, $1 \mu \mathrm{l}$ of a 1 in 100 dilution (equal to $0.0014 \mathrm{U}$ ) of E. coli alkaline phosphatase (Pharmacia Biotech, Sweden) was assayed. The tubes were equilibrated at $37^{\circ} \mathrm{C}$ and $100 \mu \mathrm{l}$ of $20 \mathrm{~mm}$ phosphatase substrate $p$-nitrophenylphosphate (Sigma) were added to each tube at $37^{\circ} \mathrm{C}$. After $40 \mathrm{~min}, 100 \mu \mathrm{l}$ of stop solution $\left(1 \mathrm{M} \mathrm{K}_{2} \mathrm{HPO}_{4}\right)$ was added and the absorbance was measured at $420 \mathrm{~nm}$. The assay of $\beta$-galactosidase activity in protein samples was based on a method described by Miller [21]. Each sample was assayed in duplicate in $1 \times \mathrm{Z}$ buffer $\left(100 \mathrm{mM} \mathrm{Na} \mathrm{NPO}_{4} .7 \mathrm{H}_{2} \mathrm{O}\right.$, $350 \mathrm{mM} \mathrm{NaH}{ }_{2} \mathrm{PO}_{4} \cdot \mathrm{H}_{2} \mathrm{O}, 10 \mathrm{mM} \mathrm{KCl}, 2 \mathrm{mM} \mathrm{MgSO}_{4}, \mathrm{pH}$ 7). After equilibration at $30^{\circ} \mathrm{C}$ for $5 \mathrm{~min}$, the reaction was started by the addition of $200 \mu$ of $\sigma$-nitrophenyl$\beta$-D-galactoside. (ONPG; Sigma) and the time taken for sufficient yellow colour to appear was recorded. The reaction was stopped by adding $500 \mu \mathrm{l}$ of $1 \mathrm{M} \mathrm{Na}_{2} \mathrm{CO}_{3}$. One unit of $\beta$-galactosidase was calculated as the amount of enzyme that liberated $1 \mu \mathrm{mol}$ of $\sigma$-nitrophenol per min at $30^{\circ} \mathrm{C}, \mathrm{pH} 7$, under the above conditions.

\section{Expression and purification of the $18-k D a$ protein}

A 444-bp fragment of the gene encoding the putative exported protein (ORF HP1085) devoid of the signal sequence was amplified from $H$. pylori CCUG 17874 genomic DNA by PCR with the following primers: 20/1, 5' TAATGAATTCACTTACACGCTAGAC 3'; 20/2, 5' TTGAGGTACCGGGACTTGATAAGC $3^{\prime}$. The PCR produced a truncated HP1085 sequence beginning five residues from the putative cleavage point of the signal sequence with an EcoRI site incorporated into the $5^{\prime}$ end and a KpnI site at the 3' end. The PCR fragment was cloned into the EcoRI$K p n$ I sites of pXa1 (Boehringer Mannheim) to create pXa-1085. PCR amplification consisted of an initial denaturation step $\left(95^{\circ} \mathrm{C}, 5 \mathrm{~min}\right)$ followed by 30 amplification cycles of denaturation $\left(95^{\circ} \mathrm{C}, 30 \mathrm{~s}\right)$, annealing $\left(50^{\circ} \mathrm{C}, 30 \mathrm{~s}\right)$ and primer extension $\left(72^{\circ} \mathrm{C}\right.$, $1 \mathrm{~min})$. Expression of the fusion protein was induced by the addition of $0.4 \mathrm{mM}$ isopropyl- $\beta$ - $\delta$-thiogalactopyranoside (IPTG) into the culture medium. The protein was purified by affinity chromatography with an APTG (4-aminophenyl- $\beta$ - $\delta$-thiogalactopyranoside) column according to the manufacturer's instructions (Boehringer Mannheim). The $\beta$-gal portion of the fusion was removed by proteolytic cleavage with factor Xa (biotin-labelled) which was subsequently removed with streptavidin gel. The cleaved $\beta$-gal portion was then removed by a second round of APTG affinity chromatography, yielding pure recombinant protein. The pure protein was electrophoresed on an SDS-PAGE gel and blotted on to a polyvinylidene difluoride (PVDF) membrane (NEN, Boston, MA, USA), stained with Coomassie Brilliant Blue (BioRad) $0.25 \%$ and excised for $\mathrm{N}$-terminal sequencing. The N-terminal amino-acid sequence analysis was performed with a pulse liquid phase sequenator (Model 477A, Applied Biosystems).

\section{PCR and Southern blot analysis}

Genomic DNA prepared from eight H. pylori clinical isolates, H. pylori CCUG 17874, H. mustelae 4298 and $H$. felis was used as the template in the PCR with primers $20 / 1$ and $20 / 2$ to amplify the 444-bp fragment of HP1085. The PCR conditions were as described above and PCR products were sequenced by automated sequencing. For Southern blot experiments, genomic DNA from Helicobacter spp. was digested with HindIII and transferred from agarose gels to a positively charged membrane (Amersham) by the Southern blot technique [16]. PCR primers 20/1 and 20/2 were used to produce a 444-bp product from $H$. pylori 17874, which was purified from an agarose gel followed by phenol-chloroform extraction for use as a probe in Southern blots. The probe was labelled with 
DIG and quantified according to the manufacturer's instructions (Boehringer Mannheim). After pre-hybidisation, the blot was hybridised with $25 \mathrm{ng}$ of probe $/ \mathrm{ml}$ of hybridisation solution (DIG Easy Hyb, Boehringer Mannheim) overnight at $42^{\circ} \mathrm{C}$. The blot was washed under moderate stringency with $1 \times \mathrm{SSC}$ at $60^{\circ} \mathrm{C}$ and developed with anti-DIG antibody conjugated to alkaline phosphatase. After incubation for $15 \mathrm{~min}$ in substrate, the blot was developed by autoradiography.

\section{Sera}

Sera were collected from 32 patients at the Wakefield Gastroenterology Centre, Wellington. Of these, 21 were infected with $H$. pylori as diagnosed by either the CLO test, urease breath test (UBT) or by testing for anti- $H$. pylori antibodies in serum (Quikview Kit). Control sera were obtained from 11 asymptomatic volunteers who were determined to be $H$. pylori negative by Quikview and CLO test (three) or by Quikview only (eight). Serum samples were stored at $-70^{\circ} \mathrm{C}$ until the immunoblots were performed. This study was approved by the Wellington Ethics Committee, Central Regional Health Authority, New Zealand.

\section{SDS-PAGE and Western blot analysis}

Electrophoresis of proteins was performed routinely on SDS-polyacrylamide gels by standard methods with a BioRad Mini Protean II apparatus according to the manufacturer's instructions. For Western blotting, $c$. $10 \mu \mathrm{g}$ of purified protein/lane were run on an SDSPAGE $12 \%$ gel and transferred to a PVDF membrane by a TransBlot semi-dry transfer cell (BioRad) according to the manufacturer's instructions. The blocking solution was PBS ( $\mathrm{pH}$ 7.4) supplemented with milk powder $2 \%$ and Tween-20 $0.01 \%$. Blots were incubated in sera diluted 1 in 200 in PBS for $2 \mathrm{~h}$ at room temperature (RT). After being washed, the membranes were incubated at room temperature for $2 \mathrm{~h}$ in anti-human IgG alkaline phosphatase-conjugated secondary antibody (Sigma) diluted 1 in 20000 in PBS. The colour reaction was developed with BCIP $0.05 \mathrm{mg} / \mathrm{ml}$ and nitroblue tetrazolium $0.01 \%$ (NBT). Protein concentrations were determined by the BCA Protein Estimation Assay (Pierce, Rockford, USA) according to the manufacturer's instructions, with bovine serum albumin as standard.

\section{Statistical analyses}

The significance of the bands formed on immunoblots to the H. pylori $18-\mathrm{kDa}$ protein for $H$. pylori-positive and -negative patient sera was evaluated by Fisher's exact test.

\section{Results}

\section{Identification of an ORF encoding an immunogenic protein}

An H. pylori genomic library was constructed in the plasmid vector pJEM11. After plating out on the substrate BCIP, $2-3 \%$ of the recombinant clones turned blue, indicating that these contained genes encoding exported proteins [13]. Sequence data from 15 blue recombinant clones demonstrated that, in each case, the gene fused to phoA contained an N-terminal sequence characteristic of a signal peptide. Searches of the $H$. pylori genome database with these sequences revealed that, in most case, the ORF identified had been designated a signal peptide by Signal-P analysis as reported by Tomb et al. [3] (Table 2). To reduce E. coli background for screening with patient antibodies, the fusion proteins were partially purified by isolation of the periplasmic space protein. Enzyme assays were carried out to confirm PhoA activity in the periplasm and $\beta$-gal activity confined to the intracellular fraction:

Table 2. Open reading frames (ORFs) identified by sequencing of pJEM11 H. pylori insert DNA from recombinant blue colonies

\begin{tabular}{ll}
\hline $\begin{array}{l}\text { HP ORF } \\
\text { (fused in-frame to phoA) }\end{array}$ & Description \\
\hline HP $0021^{*}$ & $\begin{array}{l}\text { Hypothetical protein } \\
\text { HP } 0144\end{array}$ \\
HP 0375 & Hytochrome C oxidase subunit, membrane-bound (fixN) \\
HP $0415^{*}$ & Conserved hypothetical integral membrane protein \\
HP $0567^{*}$ & Cell envelope protein \\
HP $0726^{*}$ & Hypothetical protein (OMP) \\
HP 0758 & Conserved hypothetical integral membrane protein \\
HP $0780^{*}$ & Hypothetical protein \\
HP $0896^{*}$ & Outer-membrane protein (OMP19) \\
HP $1085^{*}$ & Hypothetical protein (OMPLP) \\
HP $1117^{*}$ & Conserved hypothetical secreted protein \\
HP $1136^{*}$ & ATP synthase FO, subunit b (atpF) \\
HP $1185^{*}$ & Conserved hypothetical integral membrane protein \\
HP $1511^{*}$ & Brute force ORF \\
HP $1568^{*}$ & Hypothetical protein \\
\hline Signal peptide designated to this gene product \\
${ }^{\dagger}$ The ORFs are listed according to the nomenclature and description designated in the published \\
genome sequence [3].
\end{tabular}


$>95 \%$ of PhoA activity was found in the periplasmic fraction, with $<5 \%$ in the intracellular fraction and no detectable PhoA activity in the extracellular milieu. All $\beta$-gal activity was found in the intracellular fraction, indicating that no intracellular protein had contaminated the periplasmic fraction (data not shown). These results also indicated that the fusion protein was exported across the cytoplasmic membrane and, therefore, contained functional expression and exportation signals fused to alkaline phosphatase. The periplasmic space fractions from eight strongly blue recombinant pJEM11 clones were screened with pooled sera from five patients with $H$. pylori infection to detect B-cell epitopes in the $H$. pylori proteins. A fusion protein was identified that reacted with this pool of sera on Western blots. When tested against the individual sera, the protein was recognised by sera from all five patients infected with $H$. pylori (data not shown). The plasmid encoding this fusion protein was designated pJHp20 and selected from the pJEM11 library for further analysis. DNA sequencing and Western blotting revealed that the plasmid $\mathrm{pJHp} 20$ contained a $1.1-\mathrm{kb}$ H. pylori insert that included a 170-bp fragment of the HP1085 [3] ORF fused in-frame with the phoA gene (Fig. 1) and expressed a fusion protein $c .5 \mathrm{kDa}$ larger than native alkaline phosphatase on Western blots (data not shown). Sequence analysis with a network program, Signal-P [22], revealed that the gene contained classical signal peptide features with a potential cleavage point at residue 23 . The signal sequence consisted of a positively charged $\mathrm{N}$ domain followed by a hydrophobic stretch ( $\mathrm{H}$ domain) of 15 residues at the N-terminus (Fig. 2).

\section{Distribution of the HP1085 gene in Helicobacter species}

In the PCR, the HP1085 gene was detected as a 444-bp product in all $10 \mathrm{H}$. pylori isolates tested, but was not amplified from one strain each of $H$. mustelae or $H$. felis. Southern blot experiments were performed to confirm the absence of the HP1085 gene in chromosomal DNA from other Helicobacter spp. with the 444bp PCR amplification product amplified from $H$. pylori

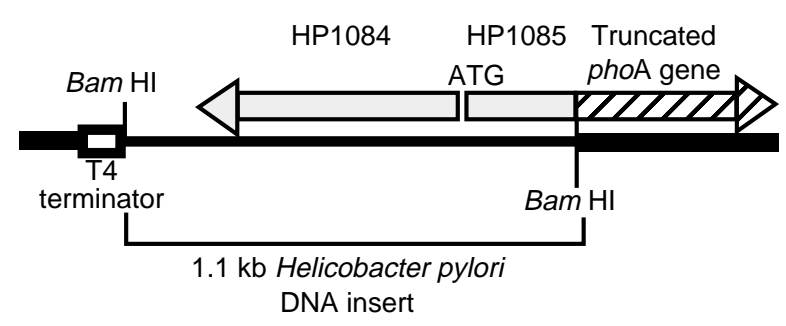

Fig. 1. Schematic diagram of pJHp20. The plasmid is an $E$. coli-mycobacterial shuttle vector (pJEM11) that carries the aph gene for kanamycin resistance. It contains a $1.1-\mathrm{kb} \mathrm{H}$. pylori insert fused to the truncated alkaline phosphatase (phoA) gene (striped). Thick black line represents vector DNA; thin black line, H. pylori insert DNA.

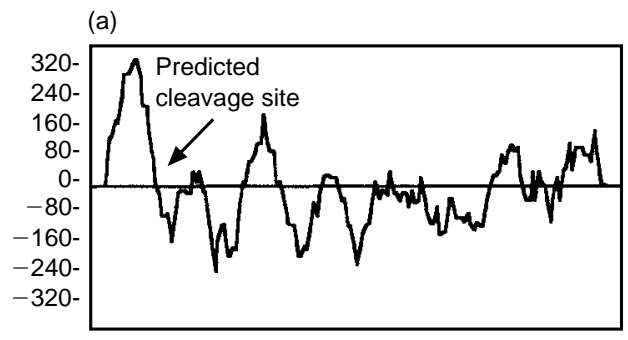

(b)

(i) $-+-++-\mathrm{n}----------+--\mathrm{n}+-+++\mathrm{n}--+---+++$

(ii) MGLKNLSTLLVFLFFCLGCVSNFNEDTYLDLVLEKK

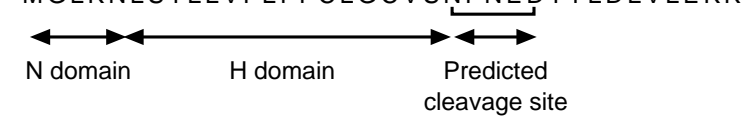

Fig. 2. (a) Kyte-Doolittle plot of the 18-kDa protein. Hydrophobic regions are shown above the line and hydrophilic below. (b) Signal sequence features of the $\mathrm{N}$-terminal region of the $18-\mathrm{kDa}$ protein showing the predicted domains and cleavage point (i) amino-acid hydropathy, (ii) amino-acid sequence. -, hydrophobic; +, hydrophilic; n, neutral.

CCUG 17874 as a probe. No hybridisation was observed with chromosomal DNA from $H$. felis or $H$. mustelae, but a strong signal was detected with $H$. pylori 17874 and clinical isolate no. 7 (data not shown). The results of this limited screen indicate that the gene may be specific to H. pylori. Furthermore, sequencing of the PCR product from five $H$. pylori clinical isolates nos. 7, 8, 38, 64 and 91) demonstrated that the gene is highly conserved, with only $0.5-3 \%$ nucleotide variation in the gene sequence compared with the type strain CCUG 17874. Also, a comparison of the $18-\mathrm{kDa}$ protein from the two $H$. pylori strains for which the genome has been sequenced $[3,4]$ revealed that there was $96.5 \%$ identity in the DNA sequence between HP1085 (strain 26695) and its counterpart JHP0340 (strain J99). The protein has not been assigned a function in either database. Searches of DNA and protein databases to identity sequence similarities with HP1085 revealed no homologies, suggesting that this gene may be unique to $H$. pylori.

\section{Purification and immunogenicity of the $18-k D a$ protein}

To overexpress the entire $18-\mathrm{kDa}$ protein, the HP1085 gene was expressed as a $\beta$-gal fusion which was purified by affinity chromatography and proteolytic cleavage of the $\beta$-gal portion. The size of the recombinant protein released is in agreement with the calculated $\mathrm{M}_{\mathrm{r}}$ of the polypeptide deduced from the DNA sequence (c. $18 \mathrm{kDa})$. N-Terminal sequencing of the purified recombinant protein confirmed its identity (data not shown). The immunogenicity of the mature protein was then determined by immunoblotting against a panel of sera. A total of 21 serum samples from $H$. pylori-infected patients and 11 from non-infected controls were collected and used in individual im- 
munoblot assays to determine the frequency of recognition of the purified protein by antibodies from infected patients. Of the $21 \mathrm{H}$. pylori-positive samples, 15 recognised the purified OMP in Western blots ( $71 \%)$, demonstrating that the protein is immunogenic during the infection process. Only two (18\%) of the 11 sera from control patients recognised the H. pylori 18 $\mathrm{kDa}$ protein $(\mathrm{p}=0.008)$ (Fig. 3).

\section{Discussion}

Several proteins secreted by or on the surface of $H$. pylori have been described as virulence factors. These include the vacuolating cytotoxin (VacA), a secreted $87-\mathrm{kDa}$ protein present in a subset of $H$. pylori strains associated with the more serious clinical outcomes of H. pylori infection [23]. Various other secreted or surface-located proteins involved in motility [24], adhesion [25] and iron uptake [26] have been identified also. Progress in identifying secreted or membrane proteins by standard biochemical techniques has been hampered by the presence of the highly immunogenic urease and GroEL homologue proteins. These normally intrinsic cytoplasmic proteins found on the surface of the bacterium are thought to be released by autolysis

\section{$\begin{array}{lllll}1 & 2 & 3 & 4 & 5\end{array}$}

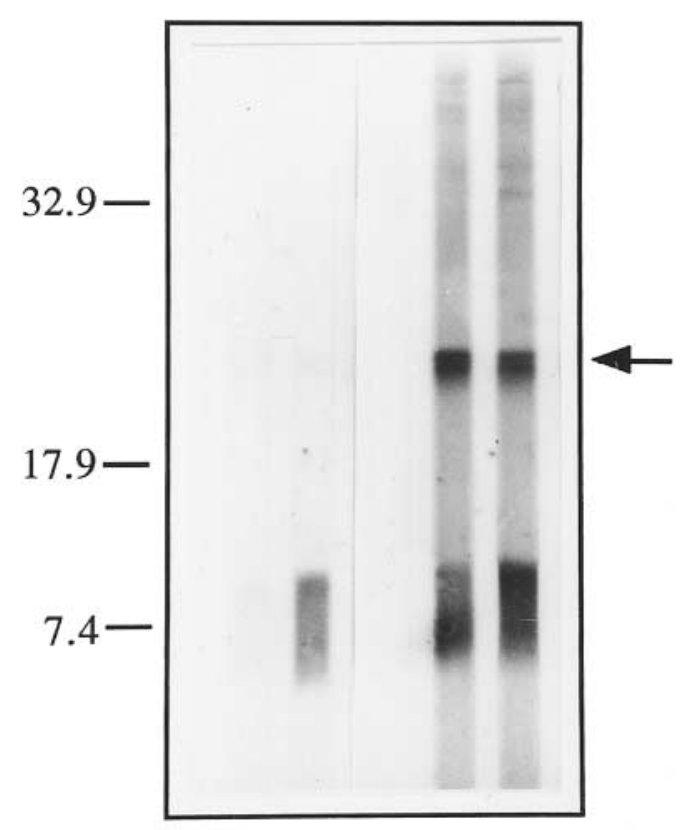

Fig. 3. Immunoblot of the $18-\mathrm{kDa}$ protein from $H$. pylori CCUG 17874. The protein was purified by affinity chromatography and analysed by SDS- $12.5 \%$ PAGE, followed by blotting and Western screening with a BioRad mini-protean II multi-screen apparatus. Lanes $\mathbf{1}$ and 2, sera from $H$. pylori non-infected patients; 3 , PBS control; 4 and $\mathbf{5}$, sera from $H$. pylori-infected patients. Arrow refers to the position of the purified $18-\mathrm{kDa} H$. pylori protein. Numbers refer to the molecular masses $(\mathrm{kDa})$ of the standard proteins.
$[11,27]$, or a novel programmed release mechanism [28].

The aim of the present study was to identify, by a genetic approach, surface-located or secreted proteins of $H$. pylori that stimulate an immune response during infection. Several translational fusion systems for the identification of bacterial export signals have been developed for enteric pathogens [29-31] and, more recently, $H$. pylori [32]. Localisation of proteins at the bacterial surface is the result of complex targeting processes, involving exportation signals and interaction with bacterial membranes. In most cases, cell membrane-associated and secreted proteins of gram-negative bacteria contain a characteristic signal peptide that directs their export across the cytoplasmic membrane via the general secretory pathway [33]. To identify exported proteins of $H$. pylori, a library was constructed based on PhoA fusion methodology [13], orginally developed to identify exported proteins in mycobacteria [14]. With this system, H. pylori sequences were identified that encode signals for the export of a large number of $H$. pylori proteins [13].

Screening of a number of these $H$. pylori PhoA fusion proteins with sera from infected patients led to the identification of one recombinant fusion protein that was strongly recognised by patients' antibodies. Sequencing revealed that the gene partially encoded an $18-\mathrm{kDa}$ putative outer-membrane protein (OMP) [3] and contained a classical signal sequence and potential transmembrane domains. The full gene encoding the $18-\mathrm{kDa}$ protein was cloned, expressed as a $\beta$-Gal fusion and the recombinant protein was purified by affinity chromatography. When a combination of Southern blot analysis and PCR was used, the gene was not found in H. felis or H. mustelae, but as only one strain of each species was screened, it is possible that the gene may be present in other strains or that it might be detected under less stringent conditions. Nevertheless, these results, and the absence of any homology to sequences in the databases, suggest that the gene may be specific to H. pylori. It is present in different clinical isolates from New Zealand and the geographically diverse type strains CCUG 17874, 26695 [3] and J99 [4]. A comparison of the DNA sequence of HP1085 from five $H$. pylori isolates and the three type strains showed a variation of up to $3.5 \%$ in the DNA sequence, suggesting that the gene is highly conserved. This is consistent with the $2-5 \%$ variation frequently observed when nucleotide sequences of conserved genes from different $H$. pylori isolates are compared. This was observed in the case of the urease genes and the heatshock protein gene $h s p \mathrm{~B}$ [34]

Infection with $H$. pylori in man results in a strong humoral immune response, characterised by high levels of both secretory IgA and serum IgG antibodies to $H$. pylori immunodominant antigens. Western blot analysis of $H$. pylori protein with patients' sera as the primary 
antibody has demonstrated that several immunodominant proteins are involved in the infection, but many of these remain to be identified. To investigate the role of the $18-\mathrm{kDa}$ protein in the antibody response, the purified recombinant protein was used in Western blot assays against patients' sera. Sera from the majority of infected patients $(71 \%)$ recognised the protein, compared with only $16 \%$ those from uninfected controls. One patient in the study, diagnosed as negative for $H$. pylori infection but positive for antibodies to the 18 $\mathrm{kDa}$ protein on Western blot, had been diagnosed with an active duodenal ulcer 18 years previously. Therefore, this result may indicate long-lasting immunity to a previous infection or exposure to $H$. pylori. However, the possibility cannot be excluded that the initial diagnostic tests used (CLO test and Quikview) were unable to detect a low grade infection with the bacterium in the two patients positive on Western blot but diagnosed as negative for the infection.

It is known that not all $H$. pylori-infected patients produce antibodies against important $H$. pylori virulence factors such as the urease B subunit (UreB) [35] and heat-shock protein A (HspA) [36]. Recognition of these antigens and other outer-membrane proteins [35] by antibody from $H$. pylori-infected individuals varies from $35 \%(\mathrm{HspA})$ to $75 \%$ (UreB). The antibody titres in the remaining $29 \%$ of patients in the present study may have been relatively low, and therefore, below the sensitivity of Western blotting. Host factors may have some influence on the level of antibody to $H$. pylori antigens, as age has shown to be an important marker for seropositivity to the HspA antigen [36]. It is possible that the detection of antibody in only $71 \%$ of patients in this study is reflected by an absence of the $18-\mathrm{kDa}$ antigen in some strains of $H$. pylori, as demonstrated with the immunodominant CagA antigen [37]. However, the evidence presented in this study suggests that the $18-\mathrm{kDa}$ antigen is conserved among isolates. Alternatively, antibodies to this antigen may be present in all infected sera, but the immunoreactive epitopes may not be conserved among $H$. pylori strains and, therefore, no reactivity to the recombinant proteins derived from $H$. pylori strain 17874 would be observed.

Serology is used extensively to diagnose $H$. pylori infection, and is particularly useful as an initial noninvasive diagnostic tool. Sensitivities of ELISA-based methods are generally high, but these assays can be plagued by low specificity due to cross-reactivity [38]. The advantage of the immunoblot technique in serological assays is its accurate detection of antibodies that react with defined antigens from an infectious agent. Therefore, immunoblot analysis has been investigated as a more reliable alternative for serodiagnosis of H. pylori [39] and, in this study, gave an accuracy of $72.2 \%$. It is known that not all $H$. pyloriinfected patients produce antibodies against important $H$. pylori proteins such as urease [40], fumarate reductase [41] and heat-shock protein A [42]. Variable $\mathrm{IgG}$ antibody responses to immunogenic iron-repressible OMPs (IROMPs) from $H$. pylori have also been described [43].

Recent work with the Rhesus monkey as a model of $H$. pylori infection has suggested that neither secretory nor serum IgA plays a protective role against infection [44] and this has led to investigations into the role of $\mathrm{IgG}$. Experimental data have shown that administration of IgG is sufficient to confer passive protection against many diseases, including gastrointestinal infections [45]. Oral immunisation of mice with $H$. pylori bacterial sonicates, along with cholera toxin, results in the induction of specific IgG-secreting cells in the gastric mucosa and the proliferation of such antibodysecreting cells correlates with both the presence of IgG in gastric secretions and protection against $H$. felis infection [46]. Furthermore, administration of the GroES homologue of $H$. pylori increased the production of specific anti- $H$. pylori IgG1 in mice and concurrently protected against experimental $H$. felis infection [47]. Thus, induction of a strong IgG response to $H$. pylori antigens appears to be a feasible strategy in the development of vaccines to protect against $H$. pylori infection.

In summary, this report describes the use of alkaline phosphatase fusion technology to identify a number of putative exported proteins of $H$. pylori, one of which was shown to encode a highly immunogenic $18-\mathrm{kDa}$ protein. The organisation of the amino-acid sequence is consistent with an exported protein with regions of hydrophobicity in the C-terminal domain that could be involved in membrane anchorage of the protein [48]. The $18-\mathrm{kDa}$ protein was frequently recognised by antibodies in the sera of patients infected with $H$. pylori, but showed only a weak reaction with two negative patients. The finding that sera from the majority of patients positive for $H$. pylori infection recognise the $18-\mathrm{kDa}$ protein described in this paper indicates that it is expressed in vivo, is probably surface-exposed and is, therefore, worth investigating as a possible candidate for inclusion in a subunit vaccine. Further investigations are currently under way to assess its ability to produce an immune response that may protect against $H$. pylori infection in a murine animal model.

This work was funded by the Health Research Council of New Zealand and the Palmerston North Medical Research Foundation. We thank Brigitte Gicquel (Pasteur Institute, Paris, France) for providing the plasmid vector pJEM11 and Paul O'Toole (Massey University, New Zealand) for supplying the Helicobacter spp. used in this study and for critique of the manuscript.

\section{References}

1. Graham DY. Helicobacter pylori infection in the pathogenesis of duodenal ulcer and gastric cancer: a model. Gastroenterology 1997; 113: 1983-1991. 
2. Thiede C, Morgner A, Alpen B et al. What role does Helicobacter pylori eradication play in gastric MALT and gastric MALT lymphoma? Gastroenterology 1997; 113, 6 Suppl: S61-S64.

3. Tomb J-F, White O, Kerlavage AR et al. The complete genome sequence of the gastric pathogen Helicobacter pylori. Nature 1997; 388: 539-547.

4. Alm RA, Ling L-SL, Moir DT et al. Genomic-sequence comparison of two unrelated isolates of the human gastric pathogen Helicobacter pylori. Nature 1999; 397: 176-180.

5. Hook-Nikanne J, Perez-Perez GI, Blaser MJ. Antigenic characterisation of Helicobacter pylori strains from different parts of the world. Clin Diagn Lab Immunol 1997; 4: 592597.

6. Ferrero RL, Thiberge J-M, Huerre M, Labigne A. Recombinant antigens prepared from the urease subunits of Helicobacter spp.: evidence of protection in a mouse model of gastric infection. Infect Immun 1994; 62: 4981-4989.

7. Covacci A, Censini S, Bugnoli $\mathrm{M}$ et al. Molecular characterisation of the $128-\mathrm{kDa}$ immunodominant antigen of Helicobacter pylori associated with cytotoxicity and duodenal ulcer. Proc Natl Acad Sci USA 1993; 90: 5791-5795.

8. Luke CJ, Penn CW. Identification of a $29 \mathrm{kDa}$ flagellar sheath protein in Helicobacter pylori using a murine monoclonal antibody. Microbiology 1995; 141: 597-604.

9. Covacci A, Falkow S, Berg DE, Rappuoli R. Did the inheritance of a pathogenicity island modify the virulence of Helicobacter pylori? Trends Microbiol 1997; 5: 205-208.

10. Ermak TH, Ding R, Ekstein B et al. Gastritis in ureaseimmunised mice after Helicobacter felis challenge may be due to residual bacteria. Gastroenterology 1997; 113: 1118-1128.

11. Cao P, McClain MS, Forsyth MH, Cover TL. Extracellular release of antigenic proteins by Helicobacter pylori. Infect Immun 1998; 66: 2984-2986.

12. Hoffman CS, Wright A. Fusions of secreted poteins to alkaline phosphatase: an approach for studying protein secretion. Proc Natl Acad Sci USA 1985; 82: 5107-5111.

13. Johnson RD, Oliaro J, Murray A. Identification of Helicobacter pylori genes encoding exported proteins. Biomed Lett 1995; 51: $267-269$

14. Lim EM, Rauzier J, Timm $\mathrm{J}$ et al. Identification of Mycobacterium tuberculosis DNA sequences encoding exported proteins by using phoA gene fusions. J Bacteriol 1995; 177: 59-65.

15. Campbell S, Fraser A, Holliss B, Schmid J, O'Toole PW. Evidence for ethnic tropism of Helicobacter pylori. Infect Immun 1997; 65: 3708-3712.

16. Sambrook J, Fritsch EF, Maniatis T. Molecular cloning: a laboratory manual, 2nd edn. Cold Spring Harbor, NY, Cold Spring Harbor Laboratory Press. 1989.

17. Altschul SF, Gish W, Miller W, Meyers EW, Lipman DJ. Basic local alignment search tool. J Mol Biol 1990; 215: 403-410.

18. Worley KC, Wiese BA, Smith RF. BEAUTY: an enhanced BLAST-based search tool that integrates multiple biological information resources into sequence similarity search results Genome Res 1995; 5: 173-184.

19. Neu HC, Heppel LA. The release of enzymes from Escherichia coli by osmotic shock and during the formation of spheroplasts. J Biol Chem 1965; 240: 3685-3692.

20. Brickman E, Beckwith J. Anaylsis of the regulation of Escherichia coli alkaline phosphatase synthesis using deletions and phi80 transducing phages. J Mol Biol 1975; 96: 307-316.

21. Miller JH. Experiments in molecular genetics. Cold Spring Harbor, NY, Cold Spring Habor Laboratory Press. 1972.

22. Nielsen H, Engelbrecht J, Brunak S, von Heijne G. Identification of prokaryotic and eukaryotic signal peptides and prediction of their cleavage sites. Protein Eng 1997; 10: 1-6.

23. Atherton JC, Peek RM, Tham KT, Cover TL, Blaser MJ. Clinical and pathological importance of heterogeneity in vacA, the vacuolating cytotoxin gene of Helicobacter pylori. Gastroenterology 1997; 112: 92-99.

24. Schmitz A, Josenhans C, Suerbaum S. Cloning and characterisation of the Helicobacter pylori flbA gene, which codes for a membrane protein involved in coordinated expression of flagellar genes. J Bacteriol 1997; 179: 987-997.

25. Clyne M, Drumm B. Cell envelope characteristics of Helicobacter pylori: their role in adherence to mucosal surfaces and virulence. FEMS Immunol Med Microbiol 1996; 16: $141-155$
26. Dhaenens L, Szczebara F, Husson MO. Identification, characterisation, and immunogenicity of the lactoferrin-binding protein from Helicobacter pylori. Infect Immun 1997; 65: 514-518.

27. Phadnis SH, Parlow MH, Levy M et al. Surface localisation of Helicobacter pylori urease and a heat shock protein homolog requires bacterial autolysis. Infect Immun 1996; 64: 905-912.

28. Vanet A, Labigne A. Evidence for specific secretion rather than autolysis in the release of some Helicobacter pylori proteins. Infect Immun 1998; 66: 1023-1027.

29. Finlay BB, Starnbach MN, Francis CL et al. Identification and characterisation of $\mathrm{Tn}$ phoA mutants of Salmonella that are unable to pass through a polarised MDCK epithelial cell monolayer. Mol Microbiol 1988; 2: 757-766.

30. Taylor RK, Miller VL, Furlong DD, Mekalanos JJ. Use of phoA gene fusions to identify a pilus colonisation factor coordinately regulated with cholera toxin. Proc Natl Acad Sci USA 1987; 84: 2833-2837.

31. Donnenberg MS, Calderwood SB, Donohue-Rolfe A, Keusch GT, Kaper JB. Construction and analysis of Tn phoA mutants of enteropathogenic Escherichia coli unable to invade Hep-2 cells. Infect Immun 1990; 58: 1565-1571.

32. Odenbreit S, Till M, Haas R. Optimised BlaM-transposon shuttle mutagenesis of Helicobacter pylori allows the identification of novel genetic loci involved in bacterial virulence. Mol Microbiol 1996; 20: 361-373.

33. Pugsley AP. The complete general secretory pathway in gramnegative bacteria. Microbiol Rev 1993; 57: 50-108.

34. Suerbaum S, Friedrich S. Helicopter pylori does not have a hap mucinase gene that is quasi-identical to the Vibrio cholerae hap gene. Mol Microbiol 1996; 20: 1113-1114.

35. Worst DJ, Sparrius M, Kuipers EJ, Kusters JG, de Graaff J. Human serum antibody response against iron-repressible outer membrane proteins of Helicobacter pylori. FEMS Microbiol Lett 1996; 144: 29-32.

36. Perez-Perez GI, Thiberge JM, Labigne A, Blaser MJ. Relationship of immune response to heat-shock protein A and characteristics of Helicobacter pylori-infected patients. J Infect Dis 1996; 174: 1046-1150.

37. Cover TL, Glupczynski Y, Lage AP et al. Serologic detection of infection with cagA + Helicobacter pylori strains. J Clin Microbiol 1995; 33: 1496-1500.

38. Nilsson I, Ljungh A, Aleljung P, Wadstrom T. Immunoblot assay for serodiagnosis of Helicobacter pylori infections. J Clin Microbiol 1997; 35: 427-432.

39. Karvar S, Karch H, Frosch M, Burghardt W, Gross U. Use of serum-specific immunoglobulins $A$ and $G$ for detection of Helicobacter pylori infection in patients with chronic gastritis by immunoblot analysis. J Clin Microbiol 1997; 35: 3058-3061.

40. Dunn BE, Campbell GP, Perez-Perez GI, Blaser MJ. Purification and characterisation of urease from Helicobacter pylori. J Biol Chem 1990; 265: 9464-9469.

41. Birkholz S, Knipp U, Lemma E, Kröger A, Opferkuch W. Fumarate reductase of Helicobacter pylori - an immunogenic protein. J Med Microbiol 1994; 41: 56-62.

42. Ng EK, Thompson SA, Perez-Perez GI et al. Helicobacter pylori heat shock protein A: serological responses and genetic diversity. Clin Diagn Lab Immunol 1999; 6: 377-382.

43. Worst DJ, Otto BR, de Graaff J. Iron-repressible outer membrane proteins of Helicobacter pylori involved in heme uptake. Infect Immun 1995; 63: 4161-4165.

44. Dubois A, Lee CK, Fiala $\mathrm{N}$ et al. Immunisation against natural Helicobacter pylori infection in nonhuman primates. Infect Iтmu 1998; 66: 4340-4346.

45. Robbins JB, Schneerson R, Szu SC. Perspective: hypothesis: serum IgG antibody is sufficient to confer protection against infectious disease by inactivating the inoculum. $J$ Infect Dis 1995; 171: 1387-1398.

46. Ferrero RL, Thiberge J-M, Labigne A. Local immunoglobulin $\mathrm{G}$ antibodies in the stomach may contribute to immunity against Helicobacter infection in mice. Gastroenterology 1997; 113: $185-194$

47. Ferrero RL, Thiberge J-M, Kansau I, Wuscher N, Huerre M, Labigne A. The GroES homolog of Helicobacter pylori confers protective immunity against mucosal infection in mice. Proc Natl Acad Sci USA 1995; 92: 6499-6503.

48. von Heijne G. Membrane protein structure prediction. Hydrophobicity analysis and the positive-inside rule. $J$ Mol Biol 1992; 225: 487-494. 